\title{
PITX2 DNA-methylation predicts response to anthracycline-based adjuvant chemotherapy in triple-negative breast cancer patients
}

\author{
MAGDALENA ABSMAIER $^{1}$, RUDOLF NAPIERALSKI ${ }^{1,7}$, TIBOR SCHUSTER ${ }^{2}$, MICHAELA AUBELE $^{5,7}$, \\ AXEL WALCH ${ }^{5,6}$, VIKTOR MAGDOLEN ${ }^{1}$, JULIA DORN $^{1}$, EVA GROSS $^{1}$, NADIA HARBECK ${ }^{4}$, \\ AURELIA NOSKE ${ }^{3}$, MARION KIECHLE $^{1}$ and MANFRED SCHMITT ${ }^{1,7}$ \\ ${ }^{1}$ Department of Obstetrics and Gynecology, ${ }^{2}$ Institute of Medical Statistics and Epidemiology, and ${ }^{3}$ Department of Pathology \\ and Pathological Anatomy, Technische Universität München, Munich; ${ }^{4}$ Breast Center, Klinikum der Ludwig Maximilians \\ Universität München, Munich; ${ }^{5}$ Institute of Pathology, Helmholtz Zentrum Muenchen, Neuherberg; ${ }^{6}$ Research Unit \\ Analytical Pathology, Helmholtz Zentrum Muenchen, Neuherberg; ${ }^{7}$ Therawis Diagnostics GmbH, Munich, Germany
}

Received June 8, 2017; Accepted October 19, 2017

DOI: $10.3892 /$ ijo.2018.4241

\begin{abstract}
Triple-negative breast cancer (TNBC) constitutes a heterogeneous breast cancer subgroup with poor prognosis; survival rates are likely to be lower with TNBC compared to other breast cancer subgroups. For this disease, systemic adjuvant chemotherapy regimens often yield suboptimal clinical results. To improve treatment regimens in TNBC, identification of molecular biomarkers may help to select patients for individualized adjuvant therapy. Evidence has accumulated that determination of the methylation status of the PITX2 gene provides a predictive value in various breast cancer subgroups, either treated with endocrine-based therapy or anthracyclinecontaining chemotherapy. To further explore the validity of this novel predictive candidate biomarker, in the present exploratory retrospective study, determination of the PITX2 DNA-methylation status was assessed for non-metastatic TNBC patients treated with adjuvant anthracycline-based chemotherapy by molecular analysis of breast cancer tissues. The PITX2 DNA-methylation status was determined in freshfrozen tumor tissue specimens $(n=56)$ by methylation-specific qRT-PCR (qMSP) and the data related to disease-free and overall survival, applying an optimized DNA-methylation score of $6.35 \%$. For non-metastatic TNBC patients treated with adjuvant systemic anthracycline-based chemotherapy, a low PITX2 DNA-methylation status $(<6.35)$ defines TNBC patients with poor disease-free and overall survival. Univariate
\end{abstract}

Correspondence to: Professor Manfred Schmitt, ${ }^{7}$ Present address: Therawis Diagnostics GmbH, Grillparzerstrasse 14, D-81675 Munich, Germany

E-mail: manfred.schmitt@therawis.com

Abbreviations: C, cyclophosphamide; M, methotrexate; F, 5-fluorouracil; E, epirubicine; gDNA, genomic DNA

Key words: PITX2, triple-negative breast cancer, anthracycline, DNA-methylation, therapy response prediction, biomarker and multivariate analyses demonstrate the statistically independent predictive value of PITX2 DNA-methylation. For non-metastatic TNBC patients, selective determination of the PITX2 DNA-methylation status may serve as a cancer biomarker for predicting response to anthracycline-based adjuvant chemotherapy. The assay based on methylation of the PIXT2 gene can be applied to frozen and routinely available formalin-fixed, paraffin-embedded (FFPE) breast cancer tumor tissues that will not only define those TNBC patients who may benefit from anthracycline-based chemotherapy but also those who should be spared the necessity of such potentially toxic treatment. Such patients should be allocated to alternative treatment options.

\section{Introduction}

Approximately $15 \%$ of breast cancers are classified as triplenegative breast cancer (TNBC), lacking expression of the estrogen receptor (ER) and the progesterone receptor (PR), and which is characterized by absence or low expression or no amplification on the gene level, of the human epidermal growth factor receptor 2 (HER2) $(1,2)$. Thus, unfortunately, breast cancer patients suffering from TNBC do not benefit from cancer therapeutics targeting these receptors. Gene expression profiling revealed that TNBC shows overlapping characteristics with the basal-like breast cancer type, including various subtypes. Patients afflicted with this malignancy are known for early disease onset with high aggressiveness, poor clinical outcome and high nuclear grade (3-9). Often, TNBCs show BRCAness, characterized by clinicopathological features normally found with BRCA1-mutated tumors (10-14).

One has to admit that little progress has been made in the last decade regarding novel, suitable druggable targets and targeted drugs for TNBC patients (15), subsequently, chemotherapy remains the essential therapeutic tool in TNBC, both in the adjuvant and the neoadjuvant setting $(3,13,15,16)$. Clinical data do suggest that the addition of platinum to anthracycline- and taxane-based chemotherapy regimens is an additional option in the treatment of both early-stage and advanced TNBC (4,17-25). 
Breast cancer patients who are undergoing chemotherapy have an increased risk of developing cardiovascular complications, and anthracyclines (e.g. doxorubicin, daunorubicin, idarubicin and epirubicin), are some of the most frequently used agents. The administration of non-anthracycline agents, that also may cause cardiotoxicity, frequently results in synergistic toxicity when anthracyclines are given concurrently $(26,27)$. Therefore, the identification of additional molecular biomarkers to predict response and/or potential cytotoxic side-effects to specific chemotherapeutics is still of high unmet medical need to further improve strategies to treat TNBC patients $(3,7,19)$.

Epigenetic DNA-methylation plays an important role in controlling gene activity and nucleus architecture (28-31). DNA-methylation markers were shown to have prognostic and/or predictive value, thus, being considered valuable, additive tools for physicians to choose the appropriate therapy regimen for the cancer patient (32-34). The PITX2 gene (paired-like homeodomain transcription factor 2), a member of the paired-like homeodomain transcription factor family, which in the healthy organism is known to play an important role during embryogenesis and organogenesis, might serve as a prime example $(35,36)$.

Recent data strongly suggest that methylation of certain CpG island promoters of the PITX2 gene may play an essential role in the very early stages of breast cancer pathogenesis and its methylation status being associated with response to adjuvant chemotherapy of a breast cancer patient (37-42). Thus, unexpectedly, in breast cancer patients, PITX2 emerged to be a key molecule in breast cancer pathophysiology, but not only associated with the course of the disease but also with response to adjuvant systemic endocrine or anthracyclinebased chemotherapy (39-41).

The aim of this retrospective pilot study was to demonstrate that PITX2 DNA-methylation is a potential predictive breast cancer biomarker in the triple-negative breast cancer subgroup (TNBC), treated with adjuvant anthracycline-based chemotherapy regimens. Our present results, for the first time indicate that quantitative determination of the PITX2 DNA-methylation status in primary TNBC breast cancer tissues will allow selection of those TNBC patients who most probably will benefit from anthracycline-based chemotherapy or not. Consequently, TNBC patients who possibly will not respond should be spared the potentially toxic burden of such chemotherapy, but could be allocated to alternative treatment modalities $(23,43-45)$.

\section{Materials and methods}

Materials. Unless otherwise stated, all the reagents applied in the present study were obtained from Qiagen (Hilden, Germany), Sigma-Aldrich (Taufkirchen, Germany), or Merck KGaA (Darmstadt, Germany).

Patients. Inclusion criteria for the retrospective study were breast cancer patients with histologically confirmed invasive triple-negative breast cancer $(n=56)$, no signs of distant metastasis at time of diagnosis, availability of frozen tumor tissue specimens for DNA extraction, follow-up data and signed informed patient consent. All patients were treated between 1991 and 2006 at the Department of Obstetrics and Gynecology, Klinikum rechts der Isar, Technical University of Munich, Munich, Germany. Study approval was obtained from the Ethics Committee of the Medical Faculty of the Technical University of Munich. Clinical and histomorphological patientrelated data are summarized in Table I. Histopathologic tumor grade was determined according to the Nottingham modification of the Scarff-Bloom-Richardson grading scheme. Absence of estrogen receptor (ER) and/or progesterone receptor (PR) protein expression was confirmed either by the dextran-coated charcoal method, by enzyme immunoassay, or immunohistochemistry, whereby positive staining of either receptor denoted receptor positivity. Presence of human epidermal growth factor receptor 2 (HER2) expression/amplification was demonstrated by immunohistochemistry using a semi-quantitative scoring system or by fluorescent in situ hybridization analysis (40). Twenty patients were younger than 50 years at the time of diagnosis. Median time of follow-up was 74 months (range, 8-179). Fifteen patients were treated with breast conserving therapy, 41 patients with mastectomy and 51 patients received radiotherapy. TNBC patients were allocated to various types of adjuvant anthracycline-based polychemotherapy regimens including FEC ( $\mathrm{n}=19), \mathrm{EC}(\mathrm{n}=13) ; \mathrm{EC}+\mathrm{CMF}(\mathrm{n}=3)$, anthracycline plus taxane $(n=20)$, or idarubicin-based therapeutics $(n=1)$.

Immunohistochemistry. 2-4 $\mu \mathrm{m}$ thick sections were cut from FFPE blocks of TNBC breast cancer patients and mounted on microscope slides (R. Langenbrinck $\mathrm{GmbH}$, Emmendingen, Germany). Sections were deparaffinized by xylene ( 2 x $10 \mathrm{~min})$ and then rehydrated in a series of graded ethanol, followed by washing in TBS, $\mathrm{pH} \mathrm{7.6,5} \mathrm{min}$, as previously described (46). All steps were performed at room temperature. Antigen retrieval was accomplished by exposing the slides to $4 \mathrm{~min}$ of pressure cooking (WMF, Geislingen an der Steige, Germany). Since a peroxidase-dependent antibody-binding system was applied (Dako EnVision + Dual Link System; Dako Deutschland GmbH, Hamburg, Germany), endogenous peroxidase activities were blocked by use of the peroxidase/alkaline phosphatase blocking reagent (Dako Deutschland $\mathrm{GmbH}$ ). For immunohistochemical staining of PITX2 protein expressed in tumor tissues, the polyclonal rabbit antibody PITX2-484 to the human PITX2 molecule was added (1:50) in antibody diluent (Dako Deutschland $\mathrm{GmbH}$ ). Sections were stored overnight at $4^{\circ} \mathrm{C}$ to allow solid interaction of antibody PITX2484 with its target molecule PITX2 expressed in the tumor sections. After washing with TBS, the secondary horseradish peroxidase-conjugated polymer antibody to the Fc-region of rabbit immunoglobulin $\mathrm{G}$ was added according to the manufacturer's recommendation (30 min, room temperature). After another washing step with TBS, the peroxidase detection solution (3,3'-diaminobenzidine; Dako Deutschland $\mathrm{GmbH}$ ) was added ( $8 \mathrm{~min}$, room temperature). The sections were then washed with TBS, nuclei of the tissue sections counterstained, and then sealed with Pertex embedding medium as previously described (46). Stained sections were scanned and digitized using the NanoZoomer Digital Pathology RS (NDP) scanner (Hamamatsu Photonics Deutschland GmbH, Herrsching am Ammersee, Germany), utilizing the NDP scan 2.2 software. A selection of TNBC primary tumors \pm hematoxylin coun- 
Table I. Clinical and histomorphological characteristics of TNBC patients treated with adjuvant anthracycline-based chemotherapy.

\begin{tabular}{|c|c|}
\hline Characteristics & $(\mathrm{n}=56)(\%)$ \\
\hline \multicolumn{2}{|l|}{ Age at time of diagnosis (years) } \\
\hline$<50$ & $20(35.7)$ \\
\hline$\geq 50$ & $36(64.3)$ \\
\hline \multicolumn{2}{|l|}{ Type of surgery } \\
\hline Mastectomy & $15(26.8)$ \\
\hline Breast conserving & $41(73.2)$ \\
\hline \multicolumn{2}{|l|}{ Tumor size (cm) } \\
\hline$\leq 2$ & $18(32.1)$ \\
\hline$>2$ & $36(64.3)$ \\
\hline Not available & $2(3.6)$ \\
\hline \multicolumn{2}{|l|}{ Histological subtype } \\
\hline Invasive ductal & $42(75.0)$ \\
\hline Others & $14(25.0)$ \\
\hline \multicolumn{2}{|l|}{ Tumor grade } \\
\hline $\mathrm{G} 2$ & $4(7.1)$ \\
\hline G3 & $50(89.3)$ \\
\hline Not available & $2(3.6)$ \\
\hline \multicolumn{2}{|l|}{ Nodal status } \\
\hline Negative & $27(48.2)$ \\
\hline Positive & $28(50.0)$ \\
\hline Not available & $1(1.8)$ \\
\hline \multicolumn{2}{|l|}{ Radiotherapy } \\
\hline Yes & $51(91.1)$ \\
\hline No & $5(8.9)$ \\
\hline \multicolumn{2}{|l|}{ Adjuvant chemotherapy } \\
\hline FEC & $19(33.9)$ \\
\hline $\mathrm{EC}$ & $13(23.2)$ \\
\hline Anthracycline plus taxane & $20(35.7)$ \\
\hline EC plus $\mathrm{CMF}$ & $3(5.4)$ \\
\hline Idarubicin-based therapeutics & $1(1.8)$ \\
\hline \multicolumn{2}{|l|}{ Disease recurrence } \\
\hline Yes & $18(32.1)$ \\
\hline No & $38(67.9)$ \\
\hline \multicolumn{2}{|l|}{ Deceased } \\
\hline Yes & $16(28.6)$ \\
\hline No & $40(71.4)$ \\
\hline
\end{tabular}

In the TNBC patient group investigated $(n=56), 64 \%$ of the patients were $>50$ years at the time of diagnosis. Median time of follow-up was 74 months (range 8-179). All of the TNBC patients were either of histological grade G2 or G3; the majority (89\%) belonged to the highly undifferentiated grade G3. Node-negative and node-positive patients were equally distributed between PITX2 high and low methylated subgroups; two-third of the patients (64\%) presented with a tumor size $>2 \mathrm{~cm}$. The majority of the patients belonged to the ductal invasive breast cancer group (75\%), others encompassed the medular, lobular, or other kinds of rare malignant breast diseases. $73.2 \%(n=41)$ received breast-conserving therapy, $91.1 \% \quad(n=51)$ radiotherapy. Adjuvant anthracycline-based polychemotherapy regimens were FEC, EC, EC+CMF, anthracyclines plus taxane or another combination of anthracycline-based therapy regimen. A total of $32 \%(n=18)$ of the TNBC patients experienced disease recurrence during the time of follow-up, $28.6 \%(n=16)$ died. The 5-year DFS probability was 74.6 whereas $75.3 \%$ of the TNBC patients survived $>5$ years.
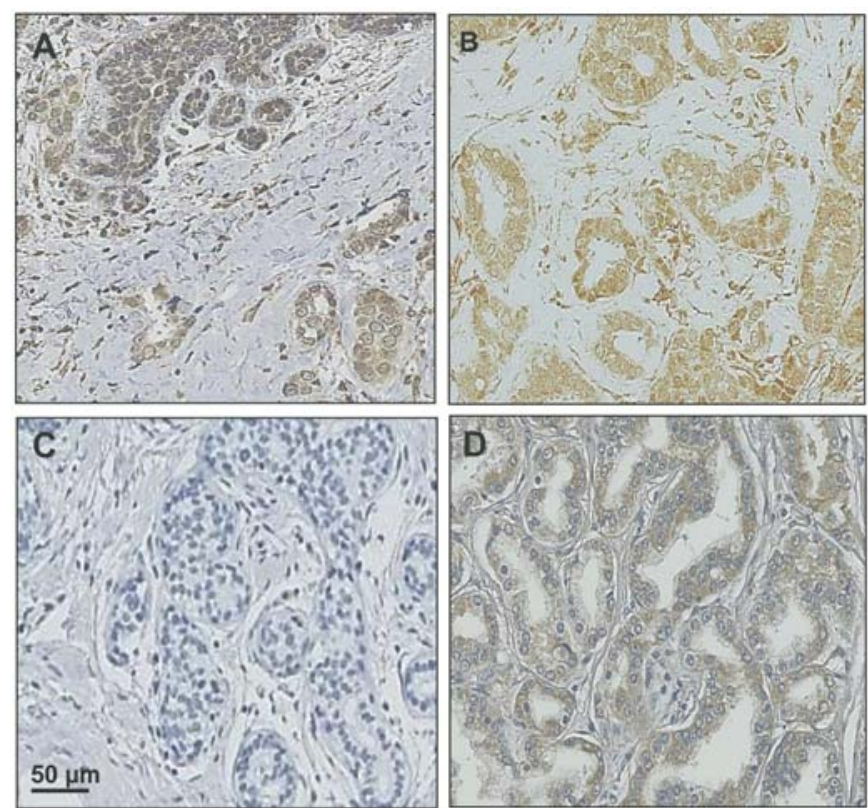

Figure 1. Immunohistochemical staining of PITX2 protein expression in TNBC tumor tissues by reaction of cellular PITX 2 with polyclonal rabbit antibody PITX2-484 to human PITX2-peptides Y and Z (residing on PITX2-B variant), expressed in breast and prostate cancer tissue. (A) Homogeneous expression of PITX2 protein (brown) in the cytoplasm of breast cancer tumor cells and scattered stromal cells. Nuclei are counterstained with hematoxylin (blue). (B) Homogeneous expression of PITX2 protein (brown) in the cytoplasm of breast cancer tumor cells, without counterstaining of nuclei with hematoxylin. Note the cytoplasmic and perinuclear/nuclear PITX2 stain. (C) Control stain, omitting antibody PITX2-484. Cells are counterstained with hematoxylin (blue). (D) Expression of PITX2 protein (brown) in the cytoplasm, sometimes perinuclear, of prostate cancer tumor cells and some stromal cells. Nuclei are counterstained with hematoxylin (blue). Formalinfixed, paraffin-embedded tissues employed; for staining details see Materials and methods.

terstain plus a prostate cancer specimen for comparison are shown in Fig. 1.

Generation of PITX2-directed antibody PITX2-484. Polyclonal antibody PITX2-484 was produced by Pineda Antibody Service (Berlin, Germany), after two PITX2peptides were selected common for all known three PITX2 variants, by generation in rabbits after combined immunization with the PITX2-derived peptides Y (aa 154-170: NGFGPQFNGLMQPYDDM) and Z (aa 243-260: NNLNNLSSPSLNSAVPTP). Peptides $Y$ and $Z$ relate to PITX2-B, which is referred to by UniProt as canonical sequence of PITX2. These peptides were synthesized plus an additional $\mathrm{N}$-terminal Cys-residue which was used for S-S-based linkage to the carrier protein KLH. Sera of the immunized rabbits were purified by affinity chromatography on vIDR-pHis (aa 153-261 of PITX2B).

DNA extraction. Immediately after excision of the primary breast tumor tissue at the Department of Obstetrics and Gynecology, Klinikum rechts der Isar, Technical University of Munich, Germany, the removed tissues were placed on ice and transported to the university's nearby pathologist to examine the removed tissue for the presence of malignant cells. Approved malignant tissue was snap-frozen and stored in the 
liquid nitrogen tumor bank of the Klinikum rechts der Isar of the Technical University of Munich until further use. On demand, tissue was removed from the liquid nitrogen storage container and the still-frozen tumor tissue pulverized by use of the Mikro-Dismembrator S (Sartorius Stedim Biotech, Göttingen, Germany), the powder was then suspended in Tris-buffered saline (0.02 M Tris-HCl/0.125 M NaCl, $\mathrm{pH}$ 8.5) containing $0.1 \%$ of the non-ionic detergent Triton $\mathrm{X}-100$, to be centrifuged at $100,000 \mathrm{x} \mathrm{g}\left(60 \mathrm{~min}, 4^{\circ} \mathrm{C}\right)(47)$. The supernatant and the cellular debris, containing the DNA-containing nuclei, were aliquoted separately and stored in liquid nitrogen until further use. Aliquots of cellular debris representing $30 \mathrm{mg}$ of breast cancer tissue were used for DNA extraction by following the QIAamp DNA Mini and Blood Mini Handbook protocol, employing the semi-automated QIAcube system (Qiagen, Hilden, Germany). Extracted genomic DNA was aliquoted and stored at $-80^{\circ} \mathrm{C}$ until further use. DNA concentration was determined by use of the NanoDrop 2000c spectrophotometer (Thermo Fisher Scientific, Wilmington, DE, USA). Breast cancer cell lines MCF-7 and MDA-MB-231 (CLS Cell Lines Service GmbH, Eppelheim, Germany), genomic unconverted DNA, and water as no template control, as well as fully methylated bisulfite-converted DNA (EpiTect PCR Control DNA Set; Qiagen) served as controls for PITX2 DNA-methylation status.

PITX2-probe and primer system specifications (according to patent EP1561821). Entrez gene ID: 5308. Amplicon length 144. Reference sequence (RefSeq) ID: NT_016354.18. Detected CpG in RefSeq: 3 CpG in 36106573 - 36106600 (39).

DNA-methylation-specific quantitative real-time PCR. For PITX2 DNA-methylation status determination, for each specimen, $310 \mathrm{ng}$ of DNA was applied in the subsequent bisulfite conversion step which was performed following the EpiTect Bisulfite Handbook protocol (Qiagen) employing an ABI PCR Cycler (Applied Biosystems, Darmstadt, Germany). Program details: $1 \mathrm{st}: 5 \mathrm{~min}$ at $99^{\circ} \mathrm{C}$. $2 \mathrm{nd}: 25 \mathrm{~min}$ at $60^{\circ} \mathrm{C}$. $3 \mathrm{rd}$ : $5 \mathrm{~min}$ at $99^{\circ} \mathrm{C}$. 4 th: $85 \mathrm{~min}$ at $60^{\circ} \mathrm{C}$. 5 th: $5 \mathrm{~min}$ at $99^{\circ} \mathrm{C}$. 6 th: $175 \mathrm{~min}$ at $60^{\circ} \mathrm{C}$. Clean-up of the bisulfite-converted DNA was carried out following the EpiTect Bisulfite kit protocol. Primers and probes for the methylated and unmethylated PITX2 DNA-methylation status were applied in a duplex probe system combined in a 10x ready to use primer and probe Master Mix; qPCR was performed according to the provider protocol (EpiTect MethyLight Assay Hs_PITX2; Qiagen) using the ABI 7000 Taqman system (Applied Biosystems). Run details: 1 st: $15 \mathrm{~min}$ at $95^{\circ} \mathrm{C}$. 2nd: 48 cycles comprising of each $15 \mathrm{sec}$ at $95^{\circ} \mathrm{C}$ and of $1 \mathrm{~min}$ at $60^{\circ} \mathrm{C}$, including $2 \mu \mathrm{l}$ primer and probe Master Mix, $2 \mu 1$ bisulfite converted DNA (7.5 ng) and $10 \mu \mathrm{l}$ QuantiTect 2x QPCR Master Mix (Qiagen), supplemented with water to a final volume of $20 \mu \mathrm{l}$. Each specimen was assessed in triplicates. A total of $5 \mathrm{ng}$ fully methylated bisulfite-converted human control DNA (Qiagen) and $7.75 \mathrm{ng}$ MCF-7 bisulfite-converted DNA served as positive controls, RNAse-free water as the negative control.

Statistics. Reporting of this study was carried out respecting the REMARK criteria $(48,49)$. For calculation of the PITX2 DNA-methylation status, the modified $\Delta \Delta C$ T-method as described by Harbeck et al (40) was employed. Mean values of triplicates were calculated for the methylated and the unmethylated PITX2 DNA-methylation status, respectively, which were then used for calculation of the individual PITX2 DNA-methylation scores. CT-values (methylated or unmethylated) obtained with $>38$ cycles were disregarded. Mean values, standard deviation, and coefficient of variation of the different qPCR runs were calculated. Only values with a coefficient of variation $<0.3$ were considered for the statistical evaluation. The relationship between PITX2 DNA-methylation score and established clinical factors to the primary endpoints disease-free (DFS) and overall survival (OS) was calculated applying univariate and multivariate Cox proportional hazard models. The date of surgery was considered as the follow-up index date. In order to discriminate between low- and high-risk patients with regards to DFS and OS, optimized cut-off values were calculated with the 'maximum-selected log-rank statistic' using the maxstat.test function as implemented from the program library 'maxstat' of the program ' $R$ ' (R Development Core Team 2012) $(50,51)$. Death before incidence of distant recurrence was considered censoring event. Survival curves were calculated according to the Kaplan-Meier method (40). The log-rank test was used for calculating the respective P-values. Cox regression models were employed for univariate risk estimation (hazard ratios, HR) for DFS and OS. Due to the limited numbers of events (disease recurrence, deaths), multivariate analyses were carried out in an exploratory fashion. For this, covariates (tumor size, tumor grading and age) were added stepwise to the variable PITX2 DNA-methylation (high vs. low) and the according hazard ratios and $95 \%$ confidence intervals depicted in forest plot diagrams in order to test whether the PITX2 DNA-methylation status adds statistically independent additional information to DFS and OS.

\section{Results}

In breast cancer, the methylation status of the PITX2 gene has previously been shown to be a clinically relevant outcome predictor in early stage breast cancer patients, either treated with endocrine (tamoxifen) therapy or anthracycline-containing chemotherapy (39-41). Applying the same technical approach as described in these publications, we now for the first time present data demonstrating the additional potential clinical utility of PITX2 DNA-methylation as a suitable biomarker to predict response to anthracycline-containing adjuvant chemotherapy in the aggressive subgroup of triple-negative breast cancer (TNBC) patients.

PITX2 DNA-methylation as a predictive candidate biomarker in TNBC patients treated with anthracycline-based adjuvant chemotherapy

Rational. An initial study investigating high-risk breast cancer patients with $\mathrm{pN}>1$ ( $>3$ affected lymph nodes) showed a clinical significance of PITX2 DNA-methylation assessment to predict response to anthracycline-containing chemotherapy (41). For this quantitative assessment of the methylation status of the PITX2 gene in primary tumor tissue samples of breast cancer patients, a quantitative methylation-specific duplex-probe qPCR system was developed, as a follow-up technology to the microarray-based screening system described in the study by 


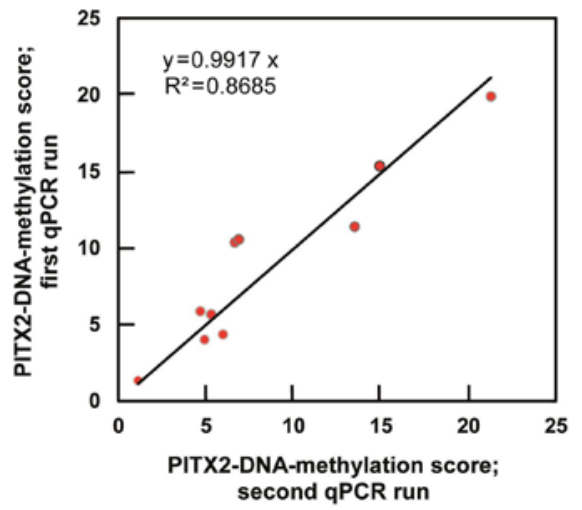

Figure 2. Independent assay replicates $(\mathrm{n}=10)$ of PITX2-DNA methylation score determination of TNBC tumor tissue samples by methylation-specific qPCR. For each of the 10 different primary TNBC tumor tissue samples, two independent PITX2-DNA-methylation measurements were carried out for the same sample. The x-axis depicts the PITX2-DNA-methylation score of the first qPCR run, the y-axis the PITX2-DNA methylation score of the second qPCR run. Linear regression analysis resulted in an R-value of 0.93 .

Maier et al (39) and tested for reliability both for ER- and PR-positive breast cancer FFPE samples (40).

With this qPCR test system, valid PITX2 DNA-methylation scores were obtained for all of the 56 TNBC patients included in this explorative biomarker study. The median PITX2 DNA-methylation score was 10.05 . An optimized cut-off value of 6.35 percent methylation ratio (PMR) for clinical impact on DFS and OS was established with the 'maximum-selected logrank statistic' using the maxstat.test function as implemented from the program library 'maxstat' of the program ' $R$ '. To analyze whether PITX2 DNA-methylation might constitute a predictive marker in TNBC, at first, univariate Cox regression analyses were performed for DFS and OS, then multivariate Cox regression analyses were carried out for DFS and OS by stepwise inclusion of the established clinicopathological factors age, tumor grading, tumor size and nodal status, as covariates for testing whether PITX2 DNA-methylation $(<6.35$ vs. $\geq 6.35 \%$ ) constitutes a statistically significant independent variable.

PITX2 DNA-methylation assay stability. PITX2 DNA-methylation assay stability and reproducibility were demonstrated by qPCR through gradual and serial dilution series of $7.75 \mathrm{ng}$ bisulfite-converted DNA obtained from the MCF-7 breast cancer cell line and two breast cancer tissues. The low coefficients of variation $(\mathrm{CV} \leq 0.06)$ obtained indicate that even with input amounts of bisulfite-converted DNA as low as $1 \mathrm{ng}$ into the qPCR reaction, PITX2 DNA-methylation scores can be determined reliably. For quality assurance and validation of the different qPCR runs, various PITX2 expression-positive and negative controls were included in each qPCR run [DNA extracted from tumor cell line MCF7, genomic unconverted DNA, fully methylated bisulfite converted DNA (EpiTect Control DNA Set; Qiagen), no-template control (water)]. The resulting low CVs $(\leq 0.08)$ evidence that stable scores could be obtained throughout the different qPCR runs. Comparison of the DNA-methylation scores of ten randomly chosen triple-negative breast cancer tumor tissue specimens, which were processed in two different qPCR runs, revealed a
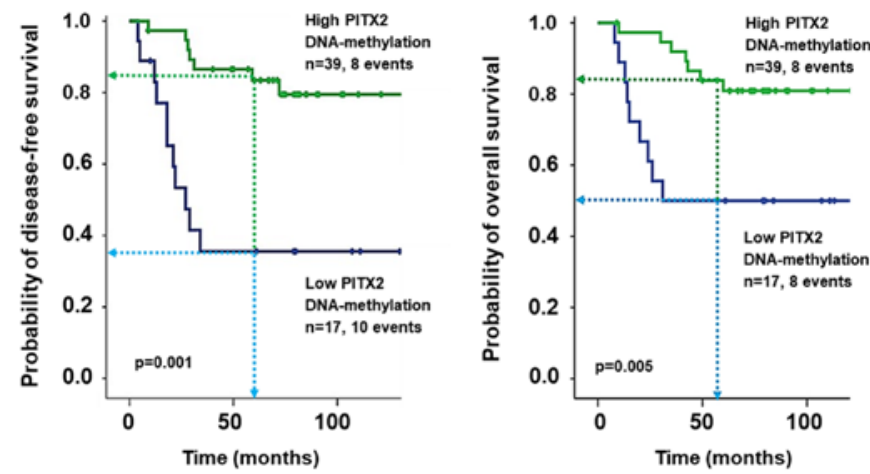

Figure 3. Kaplan-Meier analyses for DFS and OS of TNBC patients treated with adjuvant anthracycline-based chemotherapy using a defined cut-off value of 6.35 in order to estimate and graphically display empirical survival tendencies. For DFS and OS low PITX2 DNA-methylation is associated with poor clinical outcome of the patients (DFS: $\mathrm{P}<0.001,5$-year DFS 35.6 vs. $83.5 \%$; OS: $\mathrm{P}=0.005$, 5-year OS 50.0 vs. $80.9 \%$ ).

low median CV of 0.10 between the calculated PMR values of two runs with high correlation of results (r $>0.93$ ) (Fig. 2).

Allocation of PITX2 DNA-methylation scores (low vs. high) to various anthracycline-based chemotherapy regimens. Correlation with clinical outcome. The TNBC patients included in our explorative clinical study were not stratified for adjuvant anthracycline-based chemotherapy by respecting their PITX2 DNA-methylation status, but treated with anthracycline-containing adjuvant chemotherapy following the actual German AGO (Arbeitsgemeinschaft Gynaekologischer Onkologen) guidelines effective at the time of treatment (3).

Connecting clinical outcome (DFS and OS) of the 56 TNBC-patients with their treatment modalities and their respective PITX2 DNA-methylation status, we noted that the patients with low PITX2 DNA-methylation scores $<6.35$ experienced a poor clinical outcome for both DFS and OS (Table II). Remarkably, this was not only true for the EC and FEC groups, but also for the group of TNBC patients treated with anthracycline-based chemotherapy followed by taxanes. The TNBC patients allocated to the low-methylation group $(n=17)$ thus experienced ten of the disease recurrences and eight of the deaths.

In contrast, in the high-methylation group (methylation score $\geq 6.35 ; n=39$ ), only eight disease recurrences and eight of the deaths were noted in this larger group of patients, reflecting a better clinical outcome of the anthracycline-treated TNBC patients, for both DFS and OS, independent of the different anthracycline-based chemotherapy regimens.

Univariate and multivariate Cox regression analyses to assess the clinical impact of PITX 2 DNA methylation status to predict response of TNBC patients to adjuvant anthracycline-based chemotherapy. The 'maxstat.test' R-function was applied in order to search for an optimized PITX2 DNA-methylation cut-off value to distinguish TNBC patients who will respond to anthracycline-based adjuvant chemotherapy from those who will not. Using this statistical test which already accounts for multiple testing, a cut-off value of 6.35 (percentage methylation rate) was defined in order to estimate and graphically display empirical survival tendencies for DFS and OS. 
Table II. Allocation of PITX2 DNA-methylation scores (low versus high) to various anthracycline-based chemotherapy regimens.

A, Allocations of PITX2 DNA-methylation scores (low) to various anthracycline-based chemotherapy regimens.

\begin{tabular}{|c|c|c|c|c|c|c|c|}
\hline \multicolumn{6}{|c|}{$\begin{array}{l}\text { Adjuvant chemotherapy schedule } \\
\text { PITX2 DNA-methylation PMR values listed }\end{array}$} & \multicolumn{2}{|c|}{$\begin{array}{c}\text { Events } \\
\text { Low PITX2 (PMR <6.35) }\end{array}$} \\
\hline Patient & FEC & $\mathrm{EC}$ & $\mathrm{FEC}+\mathrm{CMF}$ & $\begin{array}{l}\text { Anthracycline } \\
+ \text { taxane }\end{array}$ & $\begin{array}{l}\text { Other combination of } \\
\text { anthracycline-based therapeutics }\end{array}$ & $\begin{array}{l}\text { Disease recurrence } \\
\quad \text { (months) }\end{array}$ & $\begin{array}{l}\text { Death } \\
\text { (months) }\end{array}$ \\
\hline 1 & 1.56 & & & & & 22 & 24 \\
\hline 2 & 1.78 & & & & & & \\
\hline 3 & 4.11 & & & & & 18 & 26 \\
\hline 4 & 4.31 & & & & & 12 & 14 \\
\hline 5 & 4.53 & & & & & & \\
\hline 6 & & 2.30 & & & & & \\
\hline 7 & & 2.38 & & & & 18 & 20 \\
\hline 8 & & 2.72 & & & & & \\
\hline 9 & & 5.00 & & & & 21 & 31 \\
\hline 10 & & 6.12 & & & & 27 & \\
\hline 11 & & & 3.65 & & & & \\
\hline 12 & & & & 2.39 & & 29 & \\
\hline 13 & & & & 3.52 & & & \\
\hline 14 & & & & 3.81 & & 34 & \\
\hline 15 & & & & 5.09 & & 5 & 8 \\
\hline 16 & & & & 5.52 & & 4 & 15 \\
\hline 17 & & & & & 1.19 & & 10 \\
\hline
\end{tabular}

B, Allocations of PITX2 DNA-methylation scores (high) to various anthracycline-based chemotherapy regimens.

Adjuvant chemotherapy schedule PITX2 DNA-methylation PMR values listed
Events High PITX2 (PMR $\geq 6.35)$

\begin{tabular}{|c|c|c|c|c|c|c|}
\hline Patient & FEC & $\mathrm{EC}$ & $\mathrm{FEC}+\mathrm{CMF}$ & Anthracycline + taxane & Disease recurrence (months) & Death (months) \\
\hline 18 & 6.95 & & & & 31 & 42 \\
\hline 19 & 7.70 & & & & & \\
\hline 20 & 8.70 & & & & & \\
\hline 21 & 9.17 & & & & & \\
\hline 22 & 10.05 & & & & & \\
\hline 23 & 10.53 & & & & 9 & 10 \\
\hline 24 & 12.44 & & & & & \\
\hline 25 & 20.22 & & & & 72 & \\
\hline 26 & 22.59 & & & & & \\
\hline 27 & 26.11 & & & & & \\
\hline 28 & 40.52 & & & & & \\
\hline 29 & 60.83 & & & & 59 & \\
\hline 30 & 61.78 & & & & & \\
\hline 31 & 63.65 & & & & & 60 \\
\hline 32 & & 6.35 & & & 13 & 13 \\
\hline 33 & & 6.52 & & & & \\
\hline 34 & & 11.96 & & & & \\
\hline 35 & & 20.59 & & & & \\
\hline 36 & & 21.68 & & & & \\
\hline 37 & & 29.10 & & & & \\
\hline 38 & & 40.85 & & & & \\
\hline 39 & & 47.45 & & & & 49 \\
\hline
\end{tabular}


Table II. Continued.

B, Allocations of PITX2 DNA-methylation scores (high) to various anthracycline-based chemotherapy regimens.

\begin{tabular}{|c|c|c|c|c|c|c|}
\hline \multicolumn{5}{|c|}{$\begin{array}{l}\text { Adjuvant chemotherapy schedule } \\
\text { PITX2 DNA-methylation PMR values listed }\end{array}$} & \multicolumn{2}{|c|}{$\begin{array}{c}\text { Events } \\
\text { High PITX2 }(\mathrm{PMR} \geq 6.35)\end{array}$} \\
\hline Patient & FEC & $\mathrm{EC}$ & $\mathrm{FEC}+\mathrm{CMF}$ & Anthracycline + taxane & Disease recurrence (months) & Death (months) \\
\hline 40 & & & 7.57 & & & \\
\hline 41 & & & 15.14 & & & \\
\hline 42 & & & & 6.64 & & \\
\hline 43 & & & & 8.06 & & \\
\hline 44 & & & & 8.72 & & \\
\hline 45 & & & & 8.78 & & \\
\hline 46 & & & & 9.33 & & \\
\hline 47 & & & & 11.20 & & \\
\hline 48 & & & & 13.18 & & \\
\hline 49 & & & & 13.19 & & \\
\hline 50 & & & & 14.10 & 27 & 30 \\
\hline 51 & & & & 15.18 & & \\
\hline 52 & & & & 16.91 & & \\
\hline 53 & & & & 25.60 & 29 & 35 \\
\hline 54 & & & & 38.36 & 28 & 43 \\
\hline 55 & & & & 44.10 & & \\
\hline 56 & & & & 59.47 & & \\
\hline
\end{tabular}

C, Allocation of TNBC patients to treatment groups in relation to DFS and OS events.

\begin{tabular}{llcll}
\hline Patients $(\mathrm{n})$ & Adjuvant treatment & $\begin{array}{c}\text { PITX2 DNA-methylation status } \\
\text { (Cut-off: 6.35 PMR) }\end{array}$ & DFS: Events (\%) & OS: Events (\%) \\
\hline 12 & Anthracycline, no taxane & Low & $6(50)$ & $6(50)$ \\
5 & Anthracycline plus taxane & Low & $4(80)$ & $2(40)$ \\
24 & Anthracycline, no taxane & High & $3(20.8)$ & $3(20)$ \\
15 & Anthracycline plus taxane & High & $3(20)$ &
\end{tabular}

Association with disease-free and overall survival. Listing of individual patient survival data. TNBC patients allocated to the low-methylation group A (methylation score $<6.35 ; \mathrm{n}=17$ ) experienced 10 of the disease recurrences and eight of the deaths. In contrast, in the larger high-methylation group B (methylation score $\geq 6.35 ; n=39$ ), eight disease recurrences and eight of the deaths were noted. In the low PITX2-methylation group, 5 patients were treated with FEC, 5 with EC, one with FEC + CMF, five with anthracycline + taxane and one with another combination of anthracycline-based therapeutics (idarubicin). In the high PITX2-methylation group, fourteen patients were treated with FEC, eight with EC, two with FEC $+\mathrm{CMF}$, and fifteen with anthracycline + taxane.

Both by univariate and multivariate Cox regression analyses, the PITX2 DNA-methylation status was found to contribute significant information regarding DFS and OS (Table III). Univariate analysis: DFS: HR, 5.36, 95\% CI, 2.06-13.95; OS: HR, 3.78, 95\% CI, 1.40-10.20. Multivariate analysis: DFS: HR, 6.40, 95\% CI, 1.96-20.88; OS: HR, 3.62, 95\% CI, 1.03-12.72. Concerning the established prognostic factors, only age contributed statistically significant but weak information as assessed by univariate analysis of OS (HR, $1.05,95 \%$ CI, 1.01-1.10). Kaplan-Meier analyses were carried out employing the same cut-off, regarding DFS and OS, low PITX2 DNA-methylation was associated with poor clinical outcome of the patients (DFS: $\mathrm{P}<0.001,5$-year DFS 35.6 vs. 83.5\%; OS: $\mathrm{P}=0.005,5$-year OS 50.0 vs. $80.9 \%$ ) (Fig. 3).

Evaluation of the association between PITX2-antigen expression and PITX2-DNA-methylation status in primary TNBC breast cancer tumor tissues (FFPE). PITX2 DNA-methylation score measurements and immunohistochemical staining against PITX2 applying affinity-purified antibody PITX2-484 was performed for a few randomly selected TNBC breast cancer tissues (Fig. 4). In general, in the tissues shown, immunostaining for PITX2-antigen does not match with its respective DNA-methylation status, e.g. high PITX2 
Table III. Univariate and multivariate Cox regression analyses to assess the clinical impact of PITX2 DNA-methylation status to predict response of TNBC patients to adjuvant anthracycline-based chemotherapy.

\begin{tabular}{|c|c|c|c|c|c|c|c|c|}
\hline \multirow[b]{3}{*}{ Variables } & \multicolumn{8}{|c|}{ Disease-free survival } \\
\hline & \multicolumn{4}{|c|}{ Univariate analysis } & \multicolumn{4}{|c|}{ Multivariate analysis } \\
\hline & $\mathrm{n}$ & HR & $95 \% \mathrm{CI}$ & P-value & $\mathrm{n}$ & HR & $95 \% \mathrm{CI}$ & P-value \\
\hline Tumor size & 54 & 2.75 & $0.80-9.52$ & 0.109 & 51 & 1.13 & $0.26-5.01$ & 0.871 \\
\hline Nodal status & 55 & 1.55 & $0.60-4.00$ & 0.365 & 51 & 2.04 & $0.61-6.84$ & 0.249 \\
\hline Grading & 54 & 1.30 & $0.17-9.83$ & 0.798 & 51 & 0.86 & $0.10-7.78$ & 0.893 \\
\hline Age & 56 & 1.02 & $0.98-1.06$ & 0.415 & 51 & 1.00 & $0.96-1.05$ & 0.981 \\
\hline PITX2 DNA-methylation & 56 & 5.36 & $2.06-13.95$ & 0.001 & 51 & 6.40 & $1.96-20.88$ & 0.002 \\
\hline
\end{tabular}

\begin{tabular}{|c|c|c|c|c|c|c|c|c|}
\hline \multirow[b]{3}{*}{ Variables } & \multicolumn{8}{|c|}{ Overall survival } \\
\hline & \multicolumn{4}{|c|}{ Univariate analysis } & \multicolumn{4}{|c|}{ Multivariate analysis } \\
\hline & $\mathrm{n}$ & HR & $95 \% \mathrm{CI}$ & P-value & $\mathrm{n}$ & HR & $95 \% \mathrm{CI}$ & P-value \\
\hline Tumor size & 54 & 1.62 & $0.52-5.02$ & 0.404 & 56 & 1.12 & $0.23-5.58$ & 0.886 \\
\hline Nodal status & 55 & 1.46 & $0.52-4.11$ & 0.471 & 56 & 0.99 & $0.30-3.21$ & 0.982 \\
\hline Grading & 54 & 1.09 & $0.14-8.30$ & 0.933 & 56 & 0.54 & $0.06-5.23$ & 0.594 \\
\hline Age & 56 & 1.05 & $1.01-1.10$ & 0.032 & 56 & 1.05 & $0.99-1.11$ & 0.092 \\
\hline PITX2 DNA-methylation & 56 & 3.78 & $1.40-10.20$ & 0.009 & 56 & 3.62 & $1.03-12.72$ & 0.045 \\
\hline
\end{tabular}

HR, hazard ratio; CI, confidence interval. Bold, statistically significant P-values.
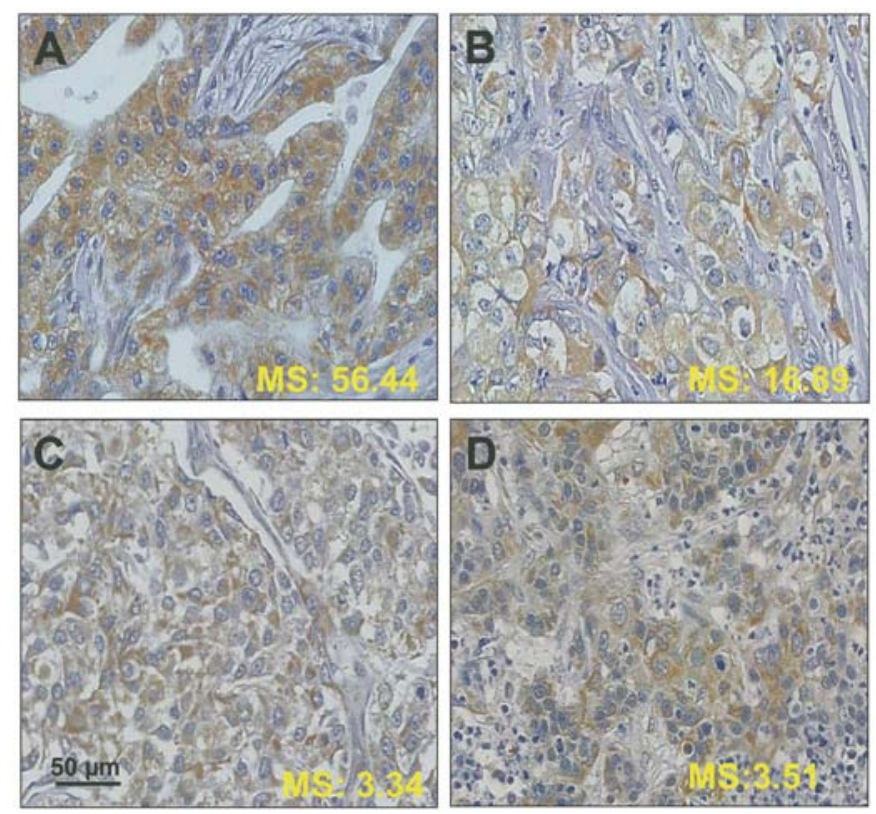

Figure 4. Association between PITX2-antigen expression in primary breas cancer tumor tissues (TNBC) and their PITX2-DNA-methylation status. The four breast cancer specimens (A-D) shown demonstrate explicit immunostaining with affinity-purified antibody PITX2-484 in the cytosol fraction and the perinucleus of the tumor cells. Obviously, the respective DNAmethylation scores are not directly correlated with PITX2-immunostaining intensity. Formalin-fixed, paraffin-embedded tissues employed; for staining details see Materials and methods.

DNA-methylation scores do not reflect a substantial decrease in immunostaining intensity.

\section{Discussion}

During embryonic development, expression of PITX2, a bicoidlike developmental transcription factor, determines the left-right symmetry of the body and tightly controls the correct placement of various internal organs $(36,52-54)$. In breast cancer, the methylation status of the PITX2 gene has been reported to be both a prognostic and a predictive biomarker for response of patients to endocrine therapy or anthracycline-based chemotherapy (39-41). In the present study, a test system was applied which determines the PITX2 DNA-methylation status in FFPE-breast cancer tumor tissues, first described by Harbeck et al (40), resulting from a multicenter trans-European cooperation of European academic and commercial partners supported by the European Union Framework Program FP6. It is a real-time quantitative methylation-specific PCR-based (qMSP) assay; the sample type is bisDNA, i.e. bisulfite-converted gDNA. For this, gDNA is extracted from FFPE breast cancer tumor tissues, then exposed to bisulfite treatment to distinguish between the methylated and unmethylated PITX2 status $(39,40)$.

DNA methylation changes in routinely available FFPE tissues or fresh-frozen tissues not only can serve as biomarkers for the detection of malignant disease and for the assessment of the clinical course of cancer disease but also as specific biomarkers to predict whether a cancer patient will respond to systemic drug therapy or not (39-41,55-61). Tests to assess promoter methylation patterns of some genes (e.g. MGMT, GSTP1, SHOX2, SEPT9, ASTN1 and ZNF671), in malignancies other than breast cancer, have already been transformed into commercially available clinical assays (e.g. by MDxHealth, Epigenomics and Oncgnostics). 
Increasing evidence suggests that aberrant PITX2 DNA methylation is not only prominent in breast cancer but is also associated with other malignant diseases, e.g. cancers of the urogenital and gastrointestinal tract, that of the thyroid and of head and neck, and of leukemia (62-71). Yet, the regulatory role that PITX2 DNA methylation plays in these diseases is still not fully explored. Further clinical studies are warranted to determine whether the results available are transferable to larger patient cohorts.

In a recent Clinical Practice Guideline published on behalf of the American Society of Clinical Oncology (ASCO), evidenced-based recommendations were published on the appropriate use of breast tumor biomarker assay results to guide decisions on adjuvant systemic therapy for women with early-stage invasive breast cancer with known ER/PR/HER2 status (72). One focal point of the guideline was to provide recommendations to physicians and patients on the potential ability of predictive biomarkers to indicate benefit of a certain chemotherapeutic for a respective class of ER/PR/HER2-positive and negative breast cancer patients. In summary, in view of the guideline panel, sufficient clinical evidence was provided in the scientific literature to recommend the use of multiplex biomarker assays to manage treatment of ER/PR-positive breast cancer patients. Such recommendation could not be given for the group of TNBC patients, which means that there is still a fundamental lack to guide decision on adjuvant systemic therapy for this group of patients (72).

This assessment supports the idea that the PITX2 assay should be considered as a novel, valuable additive clinically useful test, different from the established multiplex gene signatures as depicted by Harris et al (72). The PITX2 assay may assist the physician to guide decisions on adjuvant systemic therapy, both for the ER/PR-positive and negative (TNBC) breast cancer subsets (39-42).

The present clinical investigation centered on the question whether breast cancer patients afflicted with the aggressive TNBC subtype would benefit from anthracycline-containing adjuvant chemotherapy by grouping the respective TNBC patients to their low or high PITX2 gene methylation status. Different from that, previously published investigations described the relation of PITX2 DNA-methylation status with estrogen/progesterone receptor-positive breast cancer disease, not including the TNBC phenotype (39-42).

PITX2 DNA-methylation profiles in TNBC patients' tumor tissues apply to the methylation status of particular $\mathrm{CpG}$ sites in this gene; such changes can be used clinically as a prognostic and/or predictive marker for this kind of malignant disease $(39-42,55)$. Thus, the aim of the present study was to explore a possible statistical correlation between methylation in the promoter region of the PITX2 gene and clinical outcome of TNBC patients treated with anthracycline-based chemotherapy.

In addition, we also analyzed PITX2 protein expression in a limited number of randomly selected TNBC primary breast cancer tumor tissue specimens by immunohistochemistry, by employing the proprietary antibody PITX2-484, but did not observe any lack of PITX2-expression in the breast cancer tumor tissue specimens looked at, demonstrating that with respect to PITX2 protein expression, partial meth- ylation of $\mathrm{CpG}$ islands is not associated with complete gene silencing.

In our TNBC cases, the antibody applied (PITX2-484 to two PITX2-peptides located on canonical PITX2-variant PITX2-B) reacted predominantly with cytoplasmic PITX2 protein but occasionally nuclear and perinuclear staining was observed as well. Since PITX2 is a transcription factor, nuclear localization of PITX2 was expected. Yet, in the immunohistochemical assessment of PITX2 in breast cancer tissues presented by Wan Abdul Rahman et al (73), the authors claimed that in invasive ductal breast cancer, including TNBC, PITX2 protein expression is preferentially associated with the cytoplasm of the tumor cells. Other but single clinically relevant studies assessed cytoplasmic PITX2 protein expression in malignant diseases as well, e.g. in odontogenic tumors, thyroid and esophageal cancer $(69,74,75)$. Another study was related to PITX2-protein expression in ovarian cancer. The authors observed both cytoplasmic and nuclear localization of PITX2, depending on the malignant stage (62).

TNBC is characterized by large-scale transcriptional, mutational, and copy number heterogeneity; thus, in the past, most targeted chemotherapeutic agents have demonstrated low overall activity in unselected TNBC patients since various biological TNBC subgroups are overlapping and so far cannot be combined into a 'one-fits-all' model of TNBC biology (61,76-78). Oppositely, this molecular heterogeneity has allowed to categorize TNBC for different novel targeted therapeutic interventions, having led to ongoing innovative clinical strategies for early-stage and advanced TNBC, including immunotherapy and modified chemotherapy $(76,79)$. Besides that, TNBC is typically treated with various combinations of chemotherapy; a sequential anthracycline-taxane combination is the standard of care for TNBC (3). Yet, systemic chemotoxic treatment of TNBC patients needs to be personalized for a specific patient to suit her best, preferentially depending on the molecular characteristics of her disease, since at least ten different molecular TNBC subtypes have been identified using gene copy number and expression analyses $(3,77)$.

Many clinical studies have demonstrated that TNBC is sensitive to anthracycline-containing adjuvant chemotherapy regimens $(3,80,81)$; anthracyclines are considered to be among the most active drugs for the treatment of breast cancer by destabilizing the DNA through intercalation $(3,80,81)$. Otherwise, anthracyclines may cause severe side-effects, including cardiac toxicity, which can lead to heart failure and which therefore may hamper their optimal use in treatment of TNBC (82). The risk of TNBC patients to experience severe side-effects caused by systemic cancer treatment can be higher when other treatments, e.g. taxanes or platinum-based therapeutics are used in combination with an anthracycline $(3,83)$.

There is general consensus that for TNBC systemic adjuvant therapy anthracycline-containing regimens are the standard approach for patients after primary surgery. This is also the opinion of the American Society of Clinical Oncology (ASCO), it recommends chemotherapy treatment for TNBC patients based on the combination of an anthracycline with a taxane but does not currently recommend tailoring therapy for TNBC patients by stratifying treatment by implementing non-validated results for TNBC biomarkers, such as tumor cell surface receptors (EGFR, IGFBP, C-kit and PD-L1) which 
potentially could serve as novel target molecules to block tumor cell proliferation and dissemination (16). If comorbidities forbid the use of anthracyclines, treatment with taxane-based regimens and cyclophosphamide are recommended as alternative adjuvant treatment; treatments using paclitaxel or CMF (cyclophosphamide, methotrexate and 5-fluorouracil) should be considered as well $(45,84-87)$.

Only scarce data are available in the scientific literature naming biomarkers predictive for response of TNBC patients to anthracycline-based adjuvant chemotherapy. For example, Mori et al (88) speculated on the predictive value of BRCAness as a predictive factor for the effectiveness of anthracyclinebased adjuvant chemotherapy for patients with TNBCs. Different from that analysis, Bouchalova et al (89) demonstrated the usefulness of the biomarker BCL2 to predict the level of recurrence-free and overall survival in TNBC patients treated with anthracycline-based adjuvant chemotherapy.

More information is available for non-breast cancer patients. For these patients, especially concerning association of PITX2 DNA-methylation status with other biomarkers, several epigenetic studies were published, demonstrating co-expression of hypo- or hypermethylated biomarkers in conjunction with PITX2 DNA-methylation profiles (37,38,90-92). None of these studies, however, specifically addressed the issue of the potential benefit of adjuvant anthracycline treatment with regard to PITX2 expression or its DNA-methylation status, except the work performed by Hartmann et al (41). Obviously, there is still a strong need to address the question of anthracycline efficacy in TNBC and associated biomarkers to predict sensitivity or resistance to adjuvant anthracycline-based chemotherapy and for new cellular targets for individualized TNBC patients.

On this line, accumulated substantial evidence was presented in the past by a European EU-FP6-framework consortium that among all genes analyzed, PITX2 DNA-methylation analysis performed on routinely available FFPE-tumor tissue specimens holds promise as a novel practical assay for routine clinical use to predict outcome of these patients, treated with endocrine or anthracycline-based adjuvant therapy providing a potential link between PITX2 expression and breast cancer progression (39-42).

Otherwise, these studies on steroid hormone receptor-positive breast cancer were different from the present investigation which exclusively focusses on the TNBC subgroup of breast cancer patients, lacking both ER/PR-steroid hormone receptor and oncoprotein HER2 expression (3). To the best of our knowledge, this is the first clinical study examining whether determination of the methylation status of the promoter region of the PITX2 gene in primary tumor tissues can serve as a biomarker to predict response of TNBC patients to adjuvant anthracycline-based chemotherapy.

Collectively, we show by statistical analyses of TNBC patients treated with anthracycline-based adjuvant chemotherapy that low PITX2 DNA-methylation is associated with poor clinical outcome, demonstrating its statistically independent nature by univariate and multivariate statistics. Notably, the PITX2-TNBC response data indicate a reverse relationship between PITX2 DNA-methylation and response to anthracycline-based TNBC when compared to the non-TNBC breast cancer studies (39-42), supporting the notion that TNBC reflects a selected kind of breast cancer disease, different in many phenotypic and genomic aspects from endocrine receptor-positive breast cancer (3). Remarkably, our results also demonstrated that the sequential addition of taxanes to adjuvant systemic anthracycline-based chemotherapy did not alter the predictive value of PITX2.

Since searching for optimised cut-off values could potentially lead to overfitting, it is important to note that this study does not claim that the optimized cut-off value defined in this anthracycline-receiving TNBC subgroup is the optimal one for future application. The pilot character of the present study is reflected by its retrospective design and the non-homogeneous therapy regimens applied but also by a small number of cases and number of events. Therefore, the current results of this first-time observation study should rather serve as a clue towards validation of the data which have to be evaluated in future clinically relevant studies.

\section{Acknowledgements}

The present study was supported in part by the Wilhelm SanderStiftung, Munich, Germany, contract number 2012.028.1. to M.A. and M.S. and 2016.024.1. to M.A., A.W., V.M. and M.S. and by the German Research Foundation (DFG), contract number DO 1772/1-1.

\section{Competing interests}

The authors declare that they have no competing interests.

\section{References}

1. Wolff AC, Hammond ME, Hicks DG, Dowsett M, McShane LM, Allison KH, Allred DC, Bartlett JM, Bilous M, Fitzgibbons P, et al; American Society of Clinical Oncology; College of American Pathologists: Recommendations for human epidermal growth factor receptor 2 testing in breast cancer: American Society of Clinical Oncology/College of American Pathologists clinical practice guideline update. J Clin Oncol 31: 3997-4013, 2013.

2. Bauer KR, Brown M, Cress RD, Parise CA and Caggiano V: Descriptive analysis of estrogen receptor (ER)-negative, progesterone receptor (PR)-negative, and HER2-negative invasive breast cancer, the so-called triple-negative phenotype: A population-based study from the California Cancer Registry. Cancer 109: 1721-1728, 2007.

3. Harbeck N and Gnant M: Breast cancer. Lancet 389: 1134-1150, 2017.

4. Jiang T, Shi W, Wali VB, Pongor LS, Li C, Lau R, Győrffy B, Lifton RP, Symmans WF, Pusztai L, et al: Predictors of chemosensitivity in triple negative breast cancer: An integrated genomic analysis. PLoS Med 13: e1002193, 2016.

5. Liedtke $\mathrm{C}$ and Kiesel L: Breast cancer molecular subtypes-modern therapeutic concepts for targeted therapy of a heterogeneous entity. Maturitas 73: 288-294, 2012.

6. Irshad S, Ellis P and Tutt A: Molecular heterogeneity of triplenegative breast cancer and its clinical implications. Curr Opin Oncol 23: 566-577, 2011.

7. Karn T, Pusztai L, Holtrich U, Iwamoto T, Shiang CY, Schmidt M, Müller V, Solbach C, Gaetje R, Hanker L, et al: Homogeneous datasets of triple negative breast cancers enable the identification of novel prognostic and predictive signatures. PLoS One 6: e28403, 2011.

8. Dent R, Trudeau M, Pritchard KI, Hanna WM, Kahn HK, Sawka CA, Lickley LA, Rawlinson E, Sun P and Narod SA: Triple-negative breast cancer: Clinical features and patterns of recurrence. Clin Cancer Res 13: 4429-4434, 2007.

9. Sørlie T, Perou CM, Tibshirani R, Aas T, Geisler S, Johnsen H, Hastie T, Eisen MB, van de Rijn M, Jeffrey SS, et al: Gene expression patterns of breast carcinomas distinguish tumor subclasses with clinical implications. Proc Natl Acad Sci USA 98: 10869-10874, 2001. 
10. Lord CJ and Ashworth A: BRCAness revisited. Nat Rev Cancer 16: 110-120, 2016.

11. Spugnesi L, Gabriele M, Scarpitta R, Tancredi M, Maresca L, Gambino G, Collavoli A, Aretini P, Bertolini I, Salvadori B, et al: Germline mutations in DNA repair genes may predict neoadjuvant therapy response in triple negative breast patients. Genes Chromosomes Cancer 55: 915-924, 2016.

12. Mori H, Kubo M, Nishimura R, Osako T, Arima N, Okumura Y, Okido M, Yamada M, Kai M, Kishimoto J, et al: BRCAness as a biomarker for predicting prognosis and response to anthracycline-based adjuvant chemotherapy for patients with triple-negative breast cancer. PLoS One 11: e0167016, 2016.

13. Sharma P: Biology and management of patients with triplenegative breast cancer. Oncologist 21: 1050-1062, 2016.

14. Lips EH, Mulder L, Oonk A, van der Kolk LE, Hogervorst FB, Imholz AL, Wesseling J, Rodenhuis S and Nederlof PM: Triplenegative breast cancer: BRCAness and concordance of clinical features with BRCA1-mutation carriers. Br J Cancer 108: 2172-2177, 2013.

15. Cardoso F, Harbeck N, Barrios CH, Bergh J, Cortés J, El Saghir N, Francis PA, Hudis CA, Ohno S, Partridge AH, et al: Research needs in breast cancer. Ann Oncol Nov 28: 208-217, 2017.

16. Fleisher B, Clarke C and Ait-Oudhia S: Current advances in biomarkers for targeted therapy in triple-negative breast cancer. Breast Cancer (Dove Med Press) 8: 183-197, 2016.

17. Telli M: Optimizing chemotherapy in triple-negative breast cancer: The role of platinum. Am Soc Clin Oncol Educ Book 33: e37-e42, 2014.

18. Guan X, Ma F, Fan Y,Zhu W, Hong R and Xu B: Platinum-based chemotherapy in triple-negative breast cancer: A systematic review and meta-analysis of randomized-controlled trials. Anticancer Drugs 26: 894-901, 2015.

19. Anders CK, Abramson V, Tan T and Dent R: The evolution of triple-negative breast cancer: From biology to novel therapeutics. Am Soc Clin Oncol Educ Book 35: 34-42, 2016.

20. Gerratana L, Fanotto V, Pelizzari G, Agostinetto E and Puglisi F: Do platinum salts fit all triple negative breast cancers? Cancer Treat Rev 48: 34-41, 2016.

21. Kern P, Kalisch A, Kolberg HC, Kimmig R, Otterbach F, von Minckwitz G, Sikov WM, Pott D and Kurbacher C: Neoadjuvant, anthracycline-free chemotherapy with carboplatin and docetaxel in triple-negative, early-stage breast cancer: A multicentric analysis of feasibility and rates of pathologic complete response. Chemotherapy 59: 387-394, 2013.

22. Zheng R, Han S, Duan C, Chen K, You Z, Jia J, Lin S, Liang L, Liu A, Long H, et al: Role of taxane and anthracycline combination regimens in the management of advanced breast cancer: a metaanalysis of randomized trials. Medicine 94:e803, 2015.

23. Adium R and Liedtke C: Neoadjuvant therapy for patients with triple negative breast cancer (TNBC). Rev Recent Clin Trials 12: 73-80, 2017.

24. von Minckwitz G, Schneeweiss A, Loibl S, Salat C, Denkert C, Rezai M, Blohmer JU, Jackisch C, Paepke S, Gerber B, et al: Neoadjuvant carboplatin in patients with triple-negative and HER2-positive early breast cancer (GeparSixto; GBG 66): A randomised phase 2 trial. Lancet Oncol 15: 747-756, 2014.

25. Nabholtz JM, Abrial C, Mouret-Reynier MA, Dauplat MM, Weber B, Gligorov J, Forest AM, Tredan O, Vanlemmens L, Petit T, et al: Multicentric neoadjuvant phase II study of panitumumab combined with an anthracycline/taxane-based chemotherapy in operable triple-negative breast cancer: Identification of biologically defined signatures predicting treatment impact. Ann Oncol 25: $1570-1577,2014$

26. McClendon AK, Dean JL, Rivadeneira DB, Yu JE, Reed CA, Gao E, Farber JL, Force T, Koch WJ and Knudsen ES: CDK4/6 inhibition antagonizes the cytotoxic response to anthracycline therapy. Cell Cycle 11: 2747-2755, 2012.

27. Reinisch M, von Minckwitz G, Harbeck N, Janni W, Kümmel S, Kaufmann M, Elling D, Nekljudova V and Loibl S: Side effects of standard adjuvant and neoadjuvant chemotherapy regimens according to age groups in primary breast cancer. Breast Care (Basel) 8: 60-66, 2013.

28. Baylin SB and Jones PA: Epigenetic determinants of cancer. Cold Spring Harb Perspect Biol 8: 8, 2016.

29. Wu Y, Sarkissyan M and Vadgama JV: Epigenetics in breast and prostate cancer. Methods Mol Biol 1238: 425-466, 2015.

30. Atalay C: Epigenetics in breast cancer. Exp Oncol 35: 246-249, 2013.
31. Jovanovic J, Rønneberg JA, Tost J and Kristensen V: The epigenetics of breast cancer. Mol Oncol 4: 242-254, 2010.

32. Basse $\mathrm{C}$ and Arock $\mathrm{M}$ : The increasing roles of epigenetics in breast cancer: Implications for pathogenicity, biomarkers, prevention and treatment. Int J Cancer 137: 2785-2794, 2015.

33. Yang X, Lay F, Han H and Jones PA: Targeting DNA methylation for epigenetic therapy. Trends Pharmacol Sci 31: 536-546, 2010.

34. Jones PA: At the tipping point for epigenetic therapies in cancer. J Clin Invest 124: 14-16, 2014.

35. Shiratori H, Yashiro K, Shen MM and Hamada H: Conserved regulation and role of Pitx2 in situs-specific morphogenesis of visceral organs. Development 133: 3015-3025, 2006.

36. Wilting $\mathrm{J}$ and Hagedorn M: Left-right asymmetry in embryonic development and breast cancer: Common molecular determinants? Curr Med Chem 18: 5519-5527, 2011

37. Jezkova E, Kajo K, Zubor P, Grendar M, Malicherova B, Mendelova A, Dokus K, Lasabova Z, Plank L and Danko J: Methylation in promoter regions of PITX2 and RASSF1A genes in association with clinicopathological features in breast cancer patients. Tumour Biol 37: 15707-15718, 2016.

38. Martens JW, Margossian AL, Schmitt M, Foekens J and Harbeck N: DNA methylation as a biomarker in breast cancer. Future Oncol 5: 1245-1256, 2009.

39. Maier S, Nimmrich I, Koenig T, Eppenberger-Castori S, Bohlmann I, Paradiso A, Spyratos F, Thomssen C, Mueller V, Nährig J, et al; European Organisation for Research and Treatment of Cancer (EORTC) PathoBiology group: DNA-methylation of the homeodomain transcription factor PITX2 reliably predicts risk of distant disease recurrence in tamoxifen-treated, nodenegative breast cancer patients--Technical and clinical validation in a multi-centre setting in collaboration with the European Organisation for Research and Treatment of Cancer (EORTC) PathoBiology group. Eur J Cancer 43: 1679-1686, 2007.

40. Harbeck N, Nimmrich I, Hartmann A, Ross JS, Cufer T, Grützmann R, Kristiansen G, Paradiso A, Hartmann O, Margossian A, et al: Multicenter study using paraffin-embedded tumor tissue testing PITX2 DNA methylation as a marker for outcome prediction in tamoxifen-treated, node-negative breast cancer patients. J Clin Oncol 26: 5036-5042, 2008.

41. Hartmann O, Spyratos F, Harbeck N, Dietrich D, Fassbender A Schmitt M, Eppenberger-Castori S, Vuaroqueaux V, Lerebours F, Welzel K, et al: DNA methylation markers predict outcome in node-positive, estrogen receptor-positive breast cancer with adjuvant anthracycline-based chemotherapy. Clin Cancer Res 15: 315-323, 2009.

42. Nimmrich I, Sieuwerts AM, Meijer-van Gelder ME, Schwope I, Bolt-de Vries J, Harbeck N, Koenig T, Hartmann O, Kluth A, Dietrich D, et al: DNA hypermethylation of PITX2 is a marker of poor prognosis in untreated lymph node-negative hormone receptor-positive breast cancer patients. Breast Cancer Res Treat 111: 429-437, 2008.

43. Kumar P and Aggarwal R: An overview of triple-negative breast cancer. Arch Gynecol Obstet 293: 247-269, 2016.

44. Loibl S, Denkert C and von Minckwitz G: Neoadjuvant treatment of breast cancer - Clinical and research perspective. Breast 24 (Suppl 2): S73-S77, 2015.

45. Liedtke C and Rody A: New treatment strategies for patients with triple-negative breast cancer. Curr Opin Obstet Gynecol 27: 77-84, 2015.

46. Yfanti C, Mengele K, Gkazepis A, Weirich G, Giersig C, Kuo WL, Tang WJ, Rosner M and Schmitt M: Expression of metalloprotease insulin-degrading enzyme insulysin in normal and malignant human tissues. Int J Mol Med 22: 421-431, 2008.

47. Schmitt M, Mengele K, Schueren E, Sweep FC, Foekens JA, Brünner N, Laabs J, Malik A and Harbeck N; European Organisation for Research and Treatment of Cancer Pathobiology Group: European Organisation for Research and Treatment of Cancer (EORTC) Pathobiology Group standard operating procedure for the preparation of human tumour tissue extracts suited for the quantitative analysis of tissue-associated biomarkers. Eur J Cancer 43: 835-844, 2007.

48. McShane LM, Altman DG, Sauerbrei W, Taube SE, Gion M and Clark GM; Statistics Subcommittee of the NCI-EORTC Working Group on Cancer Diagnostics: Reporting recommendations for tumor marker prognostic studies (REMARK). J Natl Cancer Inst 97: 1180-1184, 2005. 
49. Altman DG, McShane LM, Sauerbrei W and Taube SE: Reporting recommendations for tumor marker prognostic studies REMARK. Explanation and elaboration. PLoS Med 9: e1001216, 2012.

50. Hothorn T: Maxstat: maximally selected rank statistics. In: R package version $0.7-14$

51. Team RDCR: A language and environment for statistical computing. In: R Foundation for Statistical Computing, Vienna, Austria, 2012.

52. Blum M, Feistel K, Thumberger T and Schweickert A: The evolution and conservation of left-right patterning mechanisms. Development 141: 1603-1613, 2014.

53. Tabin CJ: The key to left-right asymmetry. Cell 127: 27-32, 2006.

54. Levin M: Left-right asymmetry in embryonic development: A comprehensive review. Mech Dev 122: 3-25, 2005.

55. Paska AV and Hudler P: Aberrant methylation patterns in cancer: A clinical view. Biochem Med (Zagreb) 25: 161-176, 2015.

56. Ahmed D, Danielsen SA, Aagesen TH, Bretthauer M, ThiisEvensen E, Hoff G, Rognum TO, Nesbakken A, Lothe RA and Lind GE: A tissue-based comparative effectiveness analysis of biomarkers for early detection of colorectal tumors. Clin Transl Gastroenterol 3: e27, 2012.

57. Berghoff AS, Hainfellner JA, Marosi C and Preusser M: Assessing MGMT methylation status and its current impact on treatment in glioblastoma. CNS Oncol 4: 47-52, 2015.

58. Darwiche K, Zarogoulidis P, Baehner K, Welter S, Tetzner R, Wohlschlaeger J, Theegarten D, Nakajima T and Freitag L: Assessment of SHOX2 methylation in EBUS-TBNA specimen improves accuracy in lung cancer staging. Ann Oncol 24 2866-2870, 2013.

59. Dietrich D, Jung M, Puetzer S, Leisse A, Holmes EE, Meller S, Uhl B, Schatz P, Ivascu C and Kristiansen G: Diagnostic and prognostic value of SHOX2 and SEPT9 DNA methylation and cytology in benign, paramalignant and malignant pleural effusions. PLoS One 8: e84225, 2013.

60. Ilse P, Biesterfeld S, Pomjanski N, Wrobel C and Schramm M: Analysis of SHOX2 methylation as an aid to cytology in lung cancer diagnosis. Cancer Genomics Proteomics 11: 251-258, 2014.

61. Székely B, Silber AL and Pusztai L: New therapeutic strategies for triple-negative breast cancer. Oncology (Williston Park) 31: 130-137, 2017.

62. Fung FK, Chan DW, Liu VW, Leung TH, Cheung AN and Ngan HY: Increased expression of PITX2 transcription factor contributes to ovarian cancer progression. PLoS One 7: e37076, 2012.

63. Kapoor S: Promising, new prognostic markers of esophageal carcinomas. APMIS 121: 1011, 2013.

64. Liu Y, Huang Y and Zhu GZ: Cyclin A1 is a transcriptional target of PITX2 and overexpressed in papillary thyroid carcinoma. Mol Cell Biochem 384: 221-227, 2013.

65. Toyota M, Kopecky KJ, Toyota MO, Jair KW, Willman CL and Issa JP: Methylation profiling in acute myeloid leukemia. Blood 97: 2823-2829, 2001.

66. Uhl B, Gevensleben H, Tolkach Y, Sailer V, Majores M, Jung M, Meller S, Stein J, Ellinger J, Dietrich D, et al: PITX2 DNA Methylation as biomarker for individualized risk assessment of prostate cancer in core biopsies. J Mol Diagn 19: 107-114, 2017

67. Wang Q, Li J, Wu W, Shen R, Jiang H, Qian Y, Tang Y, Bai T, Wu S, Wei L, et al: Smad4-dependent suppressor pituitary homeobox 2 promotes PPP2R2A-mediated inhibition of Akt pathway in pancreatic cancer. Oncotarget 7: 11208-11222, 2016.

68. Zhang JX, Chen ZH, Xu Y, Chen JW, Weng HW, Yun M, Zheng ZS, Chen C, Wu BL, Li EM, et al: Downregulation of microRNA-644a promotes esophageal squamous cell carcinoma aggressiveness and stem cell-like phenotype via dysregulation of PITX2. Clin Cancer Res 23: 298-310, 2017.

69. Zhang JX, Tong ZT, Yang L, Wang F, Chai HP, Zhang F, Xie MR Zhang AL, Wu LM, Hong H, et al: PITX2: A promising predictive biomarker of patients' prognosis and chemoradioresistance in esophageal squamous cell carcinoma. Int J Cancer 132 2567-2577, 2013

70. Sailer V, Gevensleben H, Dietrich J, Goltz D, Kristiansen G, Bootz F and Dietrich D: Clinical performance validation of PITX2 DNA methylation as prognostic biomarker in patients with head and neck squamous cell carcinoma. PLoS One 12: e0179412, 2017.
71. López JI, Angulo JC, Martín A, Sánchez-Chapado M, GonzálezCorpas A, Colás B and Ropero S: A DNA hypermethylation profile reveals new potential biomarkers for the evaluation of prognosis in urothelial bladder cancer. APMIS 125: 787-796, 2017.

72. Harris LN, Ismaila N, McShane LM, Andre F, Collyar DE, Gonzalez-Angulo AM, Hammond EH, Kuderer NM, Liu MC, Mennel RG, et al; American Society of Clinical Oncology: Use of biomarkers to guide decisions on adjuvant systemic therapy for women with early-stage invasive breast cancer: American Society of Clinical Oncology Clinical Practice Guideline. J Clin Oncol 34: 1134-1150, 2016.

73. Wan Abdul Rahman WF, Fauzi MH and Jaafar H: Expression of DNA methylation marker of paired-like homeodomain transcription factor 2 and growth receptors in invasive ductal carcinoma of the breast. Asian Pac J Cancer Prev 15: 8441-8445, 2014.

74. Bologna-Molina R, Mikami T, Pereira-Prado V, Pires FR, Carlos-Bregni R and Mosqueda-Taylor A: Primordial odontogenic tumor: An immunohistochemical profile. Med Oral Patol Oral Cir Bucal 22: e314-e323, 2017.

75. Huang Y, Guigon CJ, Fan J, Cheng SY and Zhu GZ: Pituitary homeobox 2 (PITX2) promotes thyroid carcinogenesis by activation of cyclin D2. Cell Cycle 9: 1333-1341,2010.

76. Denkert C, Liedtke C, Tutt A and von Minckwitz G: Molecular alterations in triple-negative breast cancer-the road to new treatment strategies. Lancet 389: 2430-2442, 2016.

77. Lehmann BD, Bauer JA, Chen X, Sanders ME, Chakravarthy AB, Shyr Y and Pietenpol JA: Identification of human triple-negative breast cancer subtypes and preclinical models for selection of targeted therapies. J Clin Invest 121: 2750-2767, 2011.

78. Ring BZ, Hout DR, Morris SW, Lawrence K, Schweitzer BL, Bailey DB, Lehmann BD, Pietenpol JA and Seitz RS: Generation of an algorithm based on minimal gene sets to clinically subtype triple negative breast cancer patients. BMC Cancer 16: 143, 2016.

79. Bianchini G, Balko JM, Mayer IA, Sanders ME and Gianni L: Triple-negative breast cancer: Challenges and opportunities of a heterogeneous disease. Nat Rev Clin Oncol 13: 674-690, 2016

80. Yadav BS, Sharma SC, Chanana P and Jhamb S: Systemic treatment strategies for triple-negative breast cancer. World J Clin Oncol 5: 125-133, 2014.

81. Burstein HJ: Patients with triple negative breast cancer: Is there an optimal adjuvant treatment? Breast 22 (Suppl 2): S147-S148, 2013.

82. Christenson ES, James T, Agrawal V and Park BH: Use of biomarkers for the assessment of chemotherapy-induced cardiac toxicity. Clin Biochem 48: 223-235, 2015.

83. Basso SM, Santeufemia DA, Fadda GM, Tozzoli R, D'Aurizio F and Lumachi F: Advances in the treatment of triple-negative early breast cancer. Med Chem 12: 268-272, 2016.

84. Wahba HA and El-Hadaad HA: Current approaches in treatment of triple-negative breast cancer. Cancer Biol Med 12: 106-116, 2015.

85. Yao H, He G, Yan S, Chen C, Song L, Rosol TJ and Deng X: Triple-negative breast cancer: Is there a treatment on the horizon? Oncotarget 8: 1913-1924, 2017.

86. Locatelli MA, Curigliano $G$ and Eniu A: Extended adjuvant chemotherapy in triple-negative breast cancer. Breast Care (Basel) 12: 152-158, 2017.

87. Liedtke C, Thill M, Jackisch C, Thomssen C, Müller V, Janni W and Janni W; AGO Breast Committee*: AGO Recommendations for the diagnosis and treatment of patients with early breast cancer: Update. Breast Care (Basel) 12: 172-183, 2017.

88. Mori H, Kubo M, Nishimura R, Osako T, Arima N, Okumura Y, Okido M, Yamada M, Kai M, Kishimoto J, et al: BRCAness as a biomarker for predicting prognosis and response to anthracycline-based adjuvant chemotherapy for patients with triple-negative breast cancer. PLoS One 11: e0167016, 2016.

89. Bouchalova K, Svoboda M, Kharaishvili G, Vrbkova J, Bouchal J, Trojanec R, Koudelakova V, Radova L, Cwiertka K, Hajduch M, et al: BCL2 is an independent predictor of outcome in basal-like triple-negative breast cancers treated with adjuvant anthracycline-based chemotherapy. Tumour Biol 36: 4243-4252, 2015.

90. Duffy MJ, Napieralski R, Martens JW, Span PN, Spyratos F, Sweep FC, Brunner N, Foekens JA and Schmitt M; EORTC PathoBiology Group: Methylated genes as new cancer biomarkers. Eur J Cancer 45: 335-346, 2009. 
91. Pillai SG, Dasgupta N, Siddappa CM, Watson MA, Fleming T, Trinkaus K and Aft R: Paired-like Homeodomain Transcription factor 2 expression by breast cancer bone marrow disseminated tumor cells is associated with early recurrent disease development. Breast Cancer Res Treat 153: 507-517, 2015.

92. Dietrich D, Hasinger O, Liebenberg V, Field JK, Kristiansen G and Soltermann A: DNA methylation of the homeobox genes PITX2 and SHOX2 predicts outcome in non-small-cell lung cancer patients. Diagn Mol Pathol 21: 93-104, 2012.

cC)(9) This work is licensed under a Creative Commons

Attribution-NonCommercial-NoDerivatives 4.0

International (CC BY-NC-ND 4.0) License. 